\title{
ARTICLES
}

\section{EFFECTIVENESS OF STRUCTURED TEACHING PROGRAMME ON USE OF COMMON SALT FOR TREATING UMBILICAL GRANULOMA AMONG MOTHERS}

\author{
Ms. Nahakpam Neetu Devi*| Dr. Bimla Rani** \\ * Research Scholar, Himalayan University, Itanagar, Arunachal Pradesh, India. \\ **Research Supervisor, Himalayan University, Itanagar in Arunachal Pradesh, India. \\ DOI: http://doi.org/10.47211/tg.2021.v08i04.003
}

\begin{abstract}
Background and objectives: Umbilical granuloma is the most common umbilical abnormality in the neonate. It is an over growing tissue during the healing process of the belly button. Usually occurs in reaction to a mild infection. Umbilical granuloma commonly come to attention of parents because of persistent drainage or moisture involving the umbilicus after the cord has dried and separate. The study was done to identify the effectiveness of structured teaching prgramme on use of common salt for treating umbilical granuloma among mothers attending OPD at S.V.S. hospital, Mahabubnagar, Telangana. Materials and methods: The research design adopted for the study was one group pre test and post test, which belongs to pre-experimental design. 60 Mothers were selected by using simple random sampling technique of probability sampling technique method. A structured self-administered questionnaire was used for data collection which consisted of two parts. Part A consisting of 11 demographic data of the mothers and Part $B$ consisting of 30 items regarding on use of common salt to treat umbilical granuloma among mothers. Posttest was conducted after 4 weeks. Results: The collected data was analyzed by using both descriptive and inferential statistics such as frequency and percentage distribution, mean, standard deviation, paired " $t$ " test and chi square test at 0.001 levels off significance with $59 \mathrm{df}$. The calculated ' $t$ ' value was 33.19, which is higher than the table ' $t$ ' value 3.46 at 59df with 0.001 level of significance. It shows that there is significant difference $(p<0.001)$ in pre test and post test knowledge scores. Hence it is concluded that after structured teaching programme on use of common salt for treating umbilical granuloma the knowledge scores of the mothers have been increased. Conclusion: The study has showed that there was an overall improvement in the knowledge of the mothers after implementation of structured teaching Programme.
\end{abstract}

Key words: common salt, umbilical granuloma.

ABOUT AUTHORS:

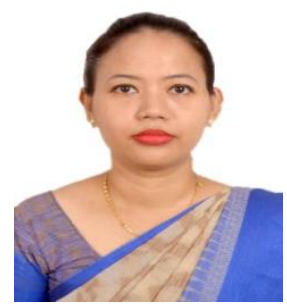

Author Ms. Nahakpam Neetu Devi is a Research Scholar at Himalayan University, Itanagar in Arunachal Pradesh, India.

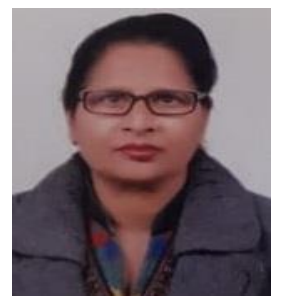

Author Dr. Bimla Rani is a Research Supervisor at Himalayan University in Itanagar, Arunachal Pradesh, India. She has presented papers in various conferences and also has many publications to her name. 


\section{ARTICLES}

\section{INTRODUCTION:}

The minor disorders are most common in newborn, neglecting the minor health problem is the one of the factor contributing to all high neonatal mortality rate is back of care of birth in India most the mothers are not aware of minor disorders of new born. It is the responsibility of the nurse to educate mother regarding the management of minor disorders of newborns.

Umbilical infections are common, but in some cases moist granulation tissue in umbilical region, redness, induration, delayed healing and abscess formation may also manifest. Umbilical infection may spread to the liver, portal vein or perineum, and can even lead to systemic infection. Umbilical granuloma is the most common umbilical abnormality in the neonate. It is an over growing tissue during the healing process of the belly button. Usually occurs in reaction to a mild infection. Pediatrician, midwife or health visitor may suggest salt treatment. This has been found to be an effective and safe treatment which you can do at home It can be simply and safely treated by applying ordinary house hold salt. Scientific reason for use of common salt has shown to be an effective practice to treat umbilical granuloma at this stage. "The principle of using this approach is thought to be through its desiccant effect and other biological properties, sodium ion in the area draws water out of the cells and results in shrinkage and necrosis of the wet granuloma tissues ". Common salt is potent, Prompt treatment, Readily available, Promotes self - care in place of medicalisation, Avoids need for prescription and dispensing processes, Avoids costs in prescribing and dispensing has no side effects, when applied for a short treatment duration, This procedure is not painful of babies.

\section{NEED FOR THE STUDY:}

Neonate's infant's mortality and morbidity are increasing day by mostly in developing countries like India. The main cause of death is infection which is a result of unhygienic practices followed by mother during newborn infant care especially in caring of cord. Umbilical granulomas are commonly identified in newborns infants. The incidence in developing countries has been quoted to be between 2 and 7 in every 100 live births. However, the incidence is even higher in communities that practice application of non-sterile home remedies to the cord.

In one study of neonates admitted to an African general pediatric ward, umbilical granuloma accounted for $28 \%$ of neonatal admissions. Hospital-based studies estimate that 2-54 babies per 1000 births will develop umbilical granuloma.

A Prospective study was conducted by use of common salt treat for umbilical granuloma. Akm Zahid Hossain, Bangladesh journal of child health. This was a clinical trial carried out on 48 infants with umbilical granuloma. The parents of 48 infants with umbilical granuloma were given instruction to treat their infants at home. The incidence of umbilical granuloma is same in both male and female. Out of total 48 infants 44 have excellent result and remaining 4 have no response. Though our study shows $91.7 \%$ excellent response and $8.3 \%$ no response of table salt for the treatment of umbilical granuloma but 4 patients were finally misdiagnosed as granuloma, the actual success rate can be taken as $100 \%$. Therefore the investigator feels that mother may have inadequate knowledge regarding use of common salt for treating umbilical granuloma

\section{PROBLEM STATEMENT:}

"To evaluate the effectiveness of structured teaching Programme on use of common salt for treating umbilical granuloma among mothers attending OPD at S.V.S. hospital, Mahabubnagar, Telangana"

\section{OBJECTIVES:}

$>$ To assess the existing knowledge on use of common salt for treating umbilical granuloma among mothers by conducting pre test.

$>$ To evaluate the effectiveness of structured teaching program on use of common salt for treating umbilical granuloma among mothers by conducting post test.

$>$ To determine the relationship between pre test and post test knowledge scores on use of common salt for treating umbilical granuloma among mothers with their selected demographic variables.

\section{HYPOTHESIS:}

$\mathbf{H}_{1}$ : There will be significant difference between pretest and post test knowledge scores among mothers regarding use of common salt for treating umbilical granuloma.

$\mathbf{H}_{2}$ : There will be significant association between post test knowledge scores among mothers regarding use of common salt for treating umbilical granuloma with selected demographic variables.

MATERIALS AND METHODS:

The research design adopted for the study was one group pre test and post test, which belongs to pre experimental design. 60 Mothers were selected by using simple random sampling technique of probability 


\section{ARTICLES}

sampling technique method. A structured self-administered questionnaire was used for data collection which consisted of two parts. Part A consisting of 11 demographic data of the mothers and Part B consisting of 30 items regarding on use of common salt to treat umbilical granuloma among mothers.

A pilot study was conducted on 16/05/2020 to 26/05/2020 at pediatric OPD of S.V.S Hospital, Mahabubnagar, Telangana, after obtaining formal permission from residential director of S.V.S Hospital to assess the feasibility and reliability of the tool. The obtained value of Karl Pearson correlation of coefficient was $r=0.99$, which infers the tool as reliable. The main study was conducted from 03/06/2020 to 04/07/2020. The collected data was analyzed by using both descriptive and inferential statistics such as frequency and percentage distribution, Mean, standard deviation, paired' test and chi square test at 0.01 level of significance with $29 \mathrm{df}$.

\section{RESULTS:}

The collected data was analyzed by using both descriptive and inferential statistics such as frequency and percentage distribution, mean, standard deviation, paired " $\mathrm{t}$ " test and chi square test at 0.001 levels off significance with $29 \mathrm{df}$. The calculated ' $t$ ' value was 15.08 which is higher than the table ' $t$ ' value 3.46 at $29 \mathrm{df}$ with 0.001 level of significance it shows that there was significant difference $(p<0.001)$ in pretest and posttest knowledge scores. The study has showed that there was an overall improvement in the knowledge of the mothers after implementation of structured teaching Programme.

Figure 1: Pre test and post test mean knowledge scores and paired t-test of significance on use of common salt for treating umbilical granuloma among mothers.

\begin{tabular}{|l|c|c|}
\hline \multicolumn{1}{|c|}{ Knowledge scores } & Pre test & Post test \\
\hline Mean & 10.4 & 22.93 \\
Standard Deviation & 2.88 & 3.03 \\
Paired t-test & \multicolumn{2}{|c|}{33.19} \\
\cline { 2 - 3 } 59df & \multicolumn{2}{|c|}{ Table t-value 3.46 } \\
\hline
\end{tabular}

Table depicts that the pre test mean was 10.4 with 2.88 standard deviation and that of post test was 22.93 with 3.03 standard deviation. The calculated ' $t$ ' value was 33.19 , which is higher than the table ' $t$ ' value 3.46 at $59 \mathrm{df}$ with 0.001 level of significance. It shows that there is significant difference $(p<0.001)$ in pre test and post test knowledge scores.

Hence it concluded after structured teaching Programme on use of common salt for treating umbilical granuloma the knowledge scores of the mothers have been increased. The positive result gives a clear indication of effectiveness of structured teaching Programme on use of common salt for treating umbilical granuloma. Hence $\mathrm{H}_{1}$ was accepted.

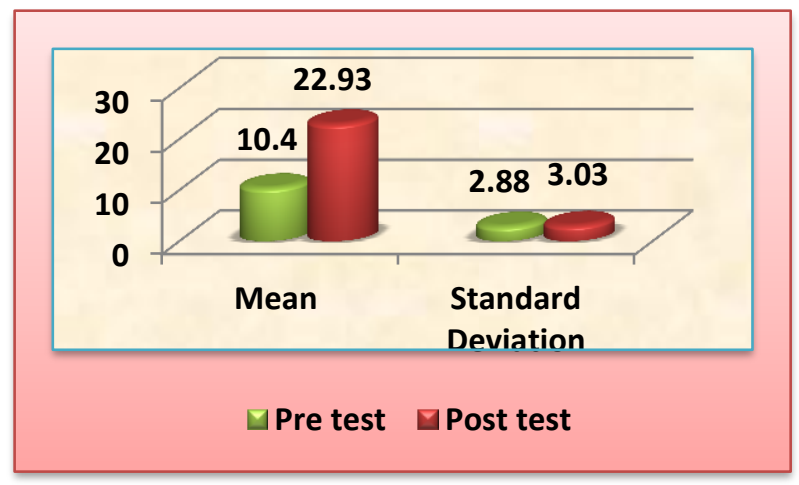

Figure 1: Pre test and post test mean knowledge scores and paired t-test of significance on use of common salt for treating umbilical granuloma among mothers.

Chi square value was computed to determine the association between the post test knowledge score with selected demographic variables of mothers. Significant association was not found between the post test knowledge score with demographic variables of mothers. Hence $\mathrm{H}_{2}$ was rejected.

\section{RECOMMENDATIONS:}

- A similar study can be carried out in various settings among mothers.

- A similar study can be replicated with experimental and control group.

- A comparative study can be conducted to evaluate the effectiveness of information booklet. 


\section{ARTICLES}

- A descriptive study can be conducted to assess the knowledge of mothers regarding use of common salt for treating umbilical granuloma among newborns in OPD.

\section{INTERPRETATION AND CONCLUSION:}

The study has showed that there was an overall improvement in the knowledge of the mothers after implementation of structured teaching Programme.

\section{REFERENCES:}

1. Achar's "Text book of pediatrics", $3^{\text {rd }}$ Edition, Published by Orient Longman Pvt. Ltd., 160, Anna Salai, Chennaiah, Pg.No.230

2. Dorthy R.Marlow" Text book of pediatric nursing " 6 th edition, published by Elsevier Health sciences Page no:

3. Dorthy Manivannan " text book of pediatric nursing " $1^{\text {st }}$ edition, published by Emmess publications Page no:330-331

4. Farhat A, Mahammadzadeh A comparison between Two and twenty four hours salt powder in treatment of infant umbilical granuloma available from http://ircmj.com /

5. Faranoush $\mathrm{M}, \mathrm{A}$ comparative study on therapeutic effect as sodium chloride and alcohol in infants with umbilical granulomas available from http://journal .qums.ac.ir/ files / site 1/user files Cc066C.

6. Kesaree N. Babu PS, Babu PS, Umbilical granuloma, available from http:/www. Indian pediatrics net/1983/Sep 1983. With.

7. O'Donnell KA, Glick PL, MG, Pediatric Umbilical Problems, Pediatric Clinics of North America 1998; 45: 791-99.

8. O. P. Ghai "Text book of essential pediatrics "7th edition, published by CBS publishers.

9. Parul datta " Text book of pediatric nursing " 2nd edition, published by Jaypee brothers medical publishers, Page no: 90

10. Pomeranz A. Anomalies, Abnormalities and Care of the umbilicus. Pediatric North Am 2004; 51:819-27

11. Zahid Hossain AKM, Therapeutic Effect of common salt on umbilical granuloma in infants available from http://www.banglajol.info / index / BJCH / article / view / 10360

12. http://www.institute. Nhs.uk/nia.

13. Sanghvi KP Best treatment for Umbilical granuloma from http;//fn.bmj.com / letters.

14. Zahid Hossain AKM, Therapeutic Effect of common salt on umbilical granuloma in infants available from http://www.banglajol.info / index / BJCH / article / view / 10360.

15. Arvin bagga ,A Text book of essential pediatrics $.8^{\text {th }}$ edition; published by CBS 751-766

16. Swarna rekha.A Text book of pediatrics. $4^{\text {th }}$ edition; published by university press $576-577,582-583$

17. R. Dorothy Marlow, A Text book of pediatric nursing . $6^{\text {th }}$; edition published by elseiver;250-25

18. Hock berry and Wilson, "The text book of Nursing Care of Newborn", $8^{\text {th }}$ edition , 2004, Elsevier publications, page no 346-349.

19. Annapurna, Therapeutic Effect of common salt on umbilical granuloma in infants available from http://www.banglajol.info / index php / BJCH / article / view / 10360.

20. Kesari ,Therapeutic Effect of common salt on umbilical granuloma in infants available from http://www.banglajol.info / index php / BJCH / article / view / 10360WWW.PUBMED.COM

21. http://connect.jbiconnectplus.org/ViewSourceFile.aspx?0=5391

22. http://preemiehelp.com/for-preemie-parents-and-carers/parenting-in-the-nicu/helping-with-preemie-inthe-nicu/optimizing-your-preemies-body-position-in-the-nicu

23. http://sids-network.org/experts/pronepos.htm

24. http://portalneonatal.com.br/metanalise.

25. Spence k, barr p; "Journal of neonatology", volume 22, 2006, page no 668-672. 